\title{
THE EFFECTS OF QUALITY CERTIFICATION IN ESTABLISHING AND DEVELOPING CUSTOMER - SUPPLIER RELATIONSHIPS
}

\author{
Isidora Miloševića ${ }^{*}$, Ana Trajkovićb, Tamara Rajićc, \\ Đorđe Nikolića and Sanela Arsića

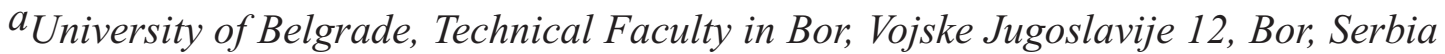

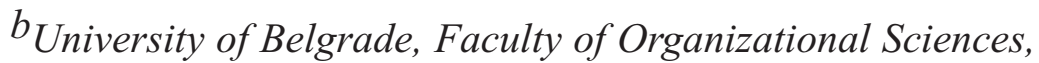 \\ Jove Ilića 154, Belgrade, Serbia \\ ${ }^{c}$ Economics Institute, Kralja Milana 16, Belgrade, Serbia
}

(Received 14 November 2016 ; accepted 23 January 2017)

\begin{abstract}
Customer-supplier relationship is extremely important for the success of the company which implies that it is necessary to maximize trust and cooperation when setting and achieving company goals. This study represents an analysis of customer -supplier relationship from the aspect of both "certified" and "non-certified" companies in Serbia. Although the number of non-certified companies in Serbia is much higher than the number of certified ones, companies that have showed interest in taking part in this research are those that have certified quality management system, even though they represent only $2.11 \%$ of the total number of companies in Serbia. The data collected in this study were analyzed in structural equation model (SEM), in which the multi-group confirmatory factor analysis (MGCFA) was used in order to perform comparative measurements using two samples from different companies- both "certified" and "non-certified" ones.
\end{abstract}

Keywords: Cooperation, Certification, Effect, Quality Management System

\section{INTRODUCTION}

In this paper we analyse the relationship between "certified" and "non-certified" companies and their suppliers. When we say certified companies (customers), we think of companies which apply quality standards (ISO 9001:2009, ISO 14000, ISO 18000) within their business systems, an integrated management system with appropriate certification (Stevenson \& Barnes, 2002).

Given that nowadays a large number of

\footnotetext{
* Corresponding author: imilosevic@tfbor.bg.ac.rs
}

DOI: $10.5937 /$ sjm13-12391 
entities participate in the market in conditions of significant interdependence regarding their cooperation, there is a strong tendency to build up mutual trust. Having in mind that implementation of ISO 9001 standard is most widely used, a certificate that confirms compliance with ISO 9001 standard requirements is now considered to be a significant element of building that trust between business partners. Thanks to the prevalence of this phenomenon, serious research on the widespread application of ISO 9001 is both necessary and important (Paulo et al., 2014).

The global network of company suppliers is increasingly playing an important role in building sustainable competitive advantages and provides support in positioning on the market as well (Wu et al., 2010; Elg et al., 2012). In the last decades, management of strategic relationships, whether vertical (customer-supplier), horizontal (strategic alliances) or lateral (with NGOs) have gained growing interest. Studies have put their focus on different types of relationships, from joint ventures or other types of alliances with particular suppliers (Ivens et al., 2013) to development of suppliers through a supplier base as well as from evaluating the quality of customersupplier relationship to meta-analytic studies with a goal to develop a generic model of marketing relationships (Modi \& Mabert, 2007; Holmen et al., 2013).

The goal of this research is an analysis of the cooperation between certified and/or non-certified companies with their suppliers. Customer-supplier relationship management has always been very important for the successes of a company. In order to adequately manage this relationship, customers and suppliers must maximize trust and cooperation, minimize opportunism and risk, and cooperate in setting and achieving goals. All these activities request open and developed communication channels (Squire et al., 2009; Holmen et al., 2013; Obal \& Lancioni, 2013). Cooperation with a particular company (available supplier companies) if in the business are insufficient or very small in number is helpful when it is possible to company (customer) to switch to other supplier if available (Sharma, 2013).

\section{THEORETICAL RESEARCH, DEVELOPMENT OF HYPOTHESES AND MODELS}

Certification process has quickly become a global phenomenon in many industries, especially today in e-markets thus creating incentive for cooperation more as a necessity for competitiveness. At the end of the $20^{\text {th }}$ century companies started researching the idea of "outsourcing" process as a way of further expense reduction, flexibility growing and achieving specialized expertise's approach (Kauffman \& Tsai, 2010).

Daimler Chrysler, researchers, business experts, industrial companies and standards organization conducted an analysis to determine the significance of certification shown in numerous "arguments, illustrations and samples". However, while "certifiers" are familiar with this information on one hand on the other hand companies "decision makers" seem to be barely aware of it. The research in companies revealed that even though some companies are not informed well enough, they are at least partially aware of the strategic potential of certification and that they can benefit from it as well. Certificates can help companies avoid dependence on one supplier since the 
availability of certificate opens an access to the market. The result is wider range of options for companies and an increased competitiveness between suppliers. Companies will also have increased trust in both quality and reliability of suppliers who have a certificate (DIN, 2000; Casadesús \& Karapetrović, 2005).

Based on literature research, we can predict that certified companies will tend to develop permanent relationships with their suppliers, since one of the principles of quality management system is: mutual beneficial relationships with suppliers should be nurtured (Castka \& Balzarova, 2008). Good relationships with suppliers can affect success factors.

Certificates play significant role in customer-supplier relationships and they can considerably add to trust and safety process (Gülçin \& Jbid, 2012). Therefore companies may also require their suppliers to implement Management System (MS) and/or get ISO certificate. According to Mitra and Datta (2014) this is especially important when a company and its suppliers are geographically dispersed, for example, United States and European companies sourcing from the South-East Asian region.

In this study, the focus is on a few benefits that are believed to influence the cooperation in customer-supplier relationships. These are trust, communication/information exchange, commitment, customer satisfaction influence and long-term orientation in cooperation. Cooperation is an expression in academic business literature widely used for discussion of relationship between customer and supplier. It refers to joint activity of partners tending to accomplish mutually compatible goals that would be either infeasible or expensive if it were otherwise (Stern \& Reve, 1980; Metcalf et al., 1992; Parkhe,
1993; Chen et al., 1998; Maloni \& Benton, 2000; Palmatier et al., 2006; Squire et al., 2009).

\subsection{Communication}

Communication plays a vital role in the development of relationship. It is as important as development of mutual values and understanding as well as coordination of activities. (Stanko et al., 2007). Moreover, exchange of such information has been proved to lead to an increase in suppliers' satisfaction and an increase in trust in the integrity and reliability of companies. Effective communication can develop mutual understanding of messages from both the perspective of the company and the supplier, and it is of key importance in preventing possible (experienced) risks and uncertainties, forming expectations, resolving any misunderstanding, explaining the opportunities and making the knowledge database. (Carr \& Kaynak, 2007; Yen et al., 2011).

Significant relations between communication and trust as well as between communication and satisfaction are being demonstrated in business literature. Considering the goal of this research, it can be expected that certified companies will make great efforts to analyze their potential suppliers thoroughly. Hence communication becomes more and more important in establishing and developing relationships, having a direct influence on the level of trust that companies have in their suppliers and their own satisfaction. Its relevance, scope and nature can vary depending on whether companies' management systems are certified or not (Redondo \& Fierro, 2008). This research examines the influences concerning interpersonal conflict as well as 
influence which effective communication has on satisfaction (Hung \& Lin, 2013). This is shown through affective satisfaction and defining customer's satisfaction with a supplier as an affective state of mind resulting from evaluation of relevant aspects of customer-supplier relationship. In accordance with the previous arguments, the following hypotheses can be set:

Hypothesis 1: Exchange of information between a company and its suppliers has a positive influence on the level of trust.

Hypothesis 2: Exchange of information between a company and its suppliers has a positive influence on the level of experienced satisfaction.

\subsection{Trust}

Trust is an important aspect of relationship between company and its suppliers. Companies that have relationships of high level of trust with their suppliers are capable of effective and efficient success, they are able to respond to changes or problems and thus solve problems more easily as well as to have high performance and satisfaction among the members of the company (McDowell et al., 2013). Strong inter-organizational relationships with suppliers, based on high level of communication, commitment and trust have proven to lead to a more effective strategic alliance (Capó-Vicedo et al., 2011). Therefore, trust is an essential aspect of inter-organizational networks regardless of the size of the company and its resources. Trust is the main determinant of committed relationship. It is hard to imagine serious business commitment (dedication in business relationship) without trust. Accordingly, only when partners feel that undermined trust is being restored, they can once again become committed. Hence, a framework should be developed which would connect level of trust and level of commitment- such commitment which would involve certain activities useful for both sides for the sake of the improvement of general performance of the supply chain (Kwon \& Suh, 2005).

While satisfaction is a form of manifestation of the ability of the other side to meet relationship norms and thus show trust. So even though the two concepts are closely related, it is expected that they have different causes and consequences (Selnes, 1998). Therefore, this study has following assumptions:

Hypothesis 3: There is a positive influence of company's level of trust on the level of commitment with its suppliers.

Hypothesis 4: There is a positive influence of company's level of trust on the level of satisfaction in relationships with suppliers.

\subsection{Commitment}

Commitment has been identified as one of the key characteristics for a successful relationship. Every lasting business transaction between customer and supplier requires commitment on both sides in order to achieve their mutual goals in a supply chain. Without commitment, business relationship and supporting transactions become sensitive and vulnerable. Therefore, commitment is the basic requirement for successful relationship with the supplier (Kwon \& Suh, 2005).

In the ongoing relationship both sides expect from each other to be committed to 
what they have in common. Commitment can be manifested in different ways either by adjustment to the standards of products and services or by investing in the relationship. Commitment is also a way of responding to the needs of clients and it represents a key dimension in market orientation. For these reasons, the commitment is expected to be the main expectation or norm within the business relationship and by meeting this expectation gives the postulate that leads to customer satisfaction (Selnes, 1998). This paper points to relationship between commitment and satisfaction in customersupplier relationships. Hence the following hypothesis follows:

Hypothesis 5: Company's level of commitment to its suppliers has a positive influence on the level of satisfaction.

\subsection{Satisfaction}

The main topic in the economic literature on relationships is to examine the factors which are necessary for achieving satisfaction in customer-supplier relationships. Earlier studies (Leonidou et al., 2008; Voldnes et al., 2012) provided a large number of such factors or benefits, including sharing information, the quality of communication and long-term orientation, level of trust, symmetric power dependence structures, appropriate exercise of power or influence strategies, degree of conflict, willingness to invest and expectations of continuity, performance roles and sense of commitment. Through numerous studies the determinants of satisfaction of the customersupplier cooperation have been examined as well as the influence of satisfaction on the orientation of long-term relationships. This discussion hypothesizes the following:
Hypothesis 6: Company's level of experienced satisfaction with its supplier has a positive influence on long-term orientation of the relationship.

Hypothesis 7: Satisfaction of companies has a positive influence on cooperation with suppliers.

\subsection{Long-term orientation}

In a long-term relationship between the customer and the supplier, the nature of the exchange is relational, characterized as one that relies on standards and common (sharing) values (Hung \& Lin, 2013). According to Webster (1992) in these longterm customer-supplier relationships, prices are output elements of the negotiation process, based on mutual dependence - not determined by the market, so the quality, delivery, and technical support are gaining in importance. Studies show that business cooperation between the customer-supplier can vary in nature. It can be both variable and stable, but they are often characterized as long-term ones (Baptista, 2013), which indicates the following hypothesis:

Hypothesis 8: There is a positive influence of the long-term orientation level on the level of cooperation.

Based on theoretical considerations, we can see that partnerships are gaining more and more attention in management as well as in academic research. Companies are increasingly encouraged to keep on track in considering benefits of cooperation in order to jointly create world-class products, attract the most valuable customers and achieve extraordinary profits (Ploetner \& Ehret, 
2006). Customer satisfaction and long-term orientation are considered possible direct benefits of cooperation among companies. Also, some of the elements that influence satisfaction and long-term orientation of the relationship are being discussed, such as, for example, communication, trust and commitment. The focus is on these factors since previous empirical studies showed their significance. Bearing in mind the objectives of this study, we assume that the main variables which affect cooperation satisfaction and long-term orientation - are likely to be under the influence of the above mentioned certification. We assume, further, that the trust, commitment and communication, which are the direct benefits of the company's level of experienced satisfaction, will also be under this influence. Therefore, following proposed hypotheses resulted with the conceptual model shown in Figure 1.

\section{METHODOLOGY}

\subsection{Sample and data collection}

In order to ensure wide applicability of our results, we have tested the hypotheses on a sample of procurement managers in different industries and sectors. Information was obtained through a questionnaire, which was realized by interviewing managers in procurement taken from the random sample of Serbian companies.

The questionnaire fundamentally consists of questions which point to demographic characteristics of companies (certified and non-certified). We established the level of certification of their quality management system where we have made use of ideas included in the literature review (Redondo \& Fierro, 2008) as well as comments made by managers in procurement. We have proposed the following levels of certification: "ISO certificate" OHSAS certificate, "international, regional and national certificates for products and services", "international, regional and national certificates for industrial processes". Aspects which relate to the following elements (level of trust in existing suppliers, exchange of information, the degree of perception of satisfaction, level of commitment to the relationship, the level of long-term orientation of the relationship and finally cooperation) have also been included.

The questionnaire consists of 22 questions, grouped in 6 categories, sent to companies in two rounds, filled in by the managers in procurement. The survey was

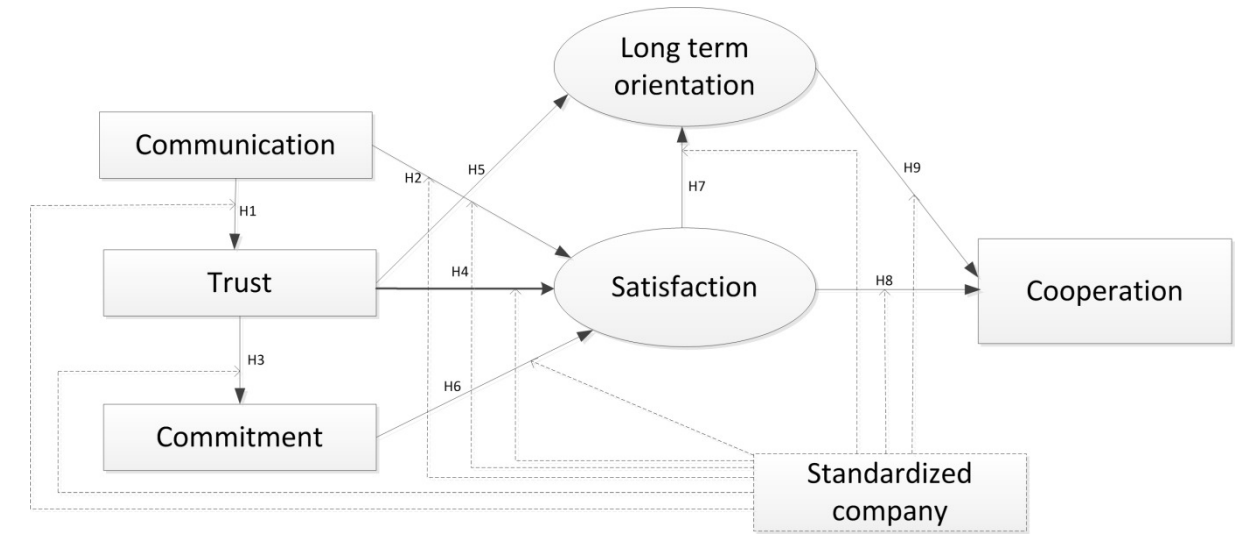

Figure 1. Conceptual model 
anonymous. In the first round questionnaires were sent to various Serbian companies, both certified and non-certified. Out of 400 questionnaires, 264 were returned, 3 of them were eliminated due to missing data and 1 due to duplicate answers on different issues. In the second round, the certification body sent questionnaires to certified companies in Serbia. Out of 300 questionnaires, 96 certified companies returned questionnaires.

In both research rounds, a total of 700 questionnaires were sent, and the final number of returned filled in questionnaires was 356 which is $50.9 \%$ of the total number of distributed questionnaires, so the sample can be regarded as representative for the population where the study was conducted. In the sample of 356 companies, 186 $(52.25 \%)$ certified companies and 170 (47.757\%) non-certified companies participated. Although the actual number of non-certified companies in Serbia is much larger than certified ones, this paper focuses on companies which achieved certain business success and continuity in work and which are developing thus having the need to organize themselves continuously. Therefore, companies that have shown more interest in participating in this research are those that tend to improve their management systems- they represent $2.11 \%$ of the total number of companies in Serbia.

Chi-square parameter test confirmed this idea. Five-point Likert scale was used for completing questionnaires (1-absolutly disagree to 5-absolutely agree).

\subsection{Measuring the model}

The obtained data were subsequently processed and analyzed by statistical techniques of numerical indicators and interpretation of results, with an emphasis on certification parameters, which differ significantly in the level of their significance and level of their implementation. As a result we have received comments on certain dimensions of suppliers as well as the global assessment of strategic cooperation, which we will use to determine measures for business success improvement within quality management system.

Data collected in this study were analyzed in structural equation model (SEM) (Živković et al., 2010), using the software package AMOS Version 8.0. Multi-group confirmatory factor analysis (MGCFA) was used for comparative measurements (Arbuckle, 2009) of two samples from both certified and non-certified companies. For testing multi-group invariance we greatly relied on studies (Byrne, 2004; Hair et al., 2010), where we tested invariance of factor loading matrix between two groups. Data analysis was threefold: the first phase consisted of identification of the basic model that best fits the data of each group respectively (configure invariance); the second phase included testing of the factor loading invariance between two groups (matrix invariance); in the third phase factorial validity was tested using the mean value as well as covariance structure analysis (MACS) which analyzes differences in mean latency values between groups (scalar invariance).

Multi-group confirmatory factor analysis includes 6 first order factors, level of trust in the existing supplier, exchange of information, the degree of perception of satisfaction, level of commitment to the relationship, the level of long-term orientation of the relationship and level of cooperation. Trust, information, satisfaction and commitment were measured by using four points, while three points were used for 
long-term orientation and cooperation (Redondo \& Fierro, 2008).

As for communication, we wanted to measure the quality, taking into account its frequency, nature, degree of formalization and relevance. The scale was suggested by Mohr et al., 1996 and Cannon \& Homburg, 2001. Trust scale shows the level of trust that customer has in supplier. Although some relevant previous research identified trust as a multidimensional concept, we opted for one-dimensionality scale which contains only concepts that suit us, following directions, of course (Baumgartner \& Homburg, 1996). Commitment scale includes different dimensions of commitment, such as: willingness to invest in the relationship; expectations of continuity; maintaining or increasing the purchase volume from the supplier; and attitude according to agreed conditions, either verbal or written. As for the volume suggested for measuring the level of perception of satisfaction, we did not consider a difference between the economic and psychological satisfaction, yet the relationship was measured both in global terms and relative to expectations formed in its initial stages. After reviewing the literature, we have developed a scale modelled after the work engagement scale (Redondo \& Fierro 2008). For measurement of long-term orientation, the scale we used is the one suggested as a reference (Walter et al., 2003). This scale measures usefulness of long-term relationship for customers and their expectations of continuity in the future consisting of three items: compensation, relevance and goals. Finally, cooperation scale analyzes the type and level of cooperation between a company and its suppliers. The scale suggested by Cannon and Homburg, (2001) considers cooperation concepts and joint solving of potential conflicts for measuring the level of relational cooperation.

In accordance with theoretical and empirical research, inter-correlation of these six factors showed results of structural invariance test, obtained by matrix examination and invariance analysis scale. Multi-group confirmatory factor analysis was performed to examine whether hypothetical model collected data adequately.

\section{DATA ANALYSIS}

In order to confirm conceptual model we performed assessment of the psychometric characteristics of scale: one-dimensionality, reliability and validity.

In order to examine interdependence within the large number of variables, which can be explained by the small number of common factors, confirmatory factor analysis was done where correlation matrix was tested while the maximum likelihood method was used as a method of assessment. The obtained results are very satisfying, indicating a proper fitting of the measuring model $\quad\left(\left(\chi^{2} \mathrm{Sat}=451.588 \quad(\mathrm{p}<0.01)\right.\right.$; RMSEA $=0.061 ; \quad \mathrm{NFI}=0.908 ; \quad \mathrm{IFI}=0.945$, $\mathrm{TLI}=0.934, \mathrm{CFI}=0.945$; Normed $\chi^{2}=2.327$ ).

All one-dimensionality scales are being determined and Cronbach's coefficient $\alpha$ (Table 1) was used for evaluation of internal consistency, where for each group of questions Nannally (1978) recommends that values $\geq 0.7$ should be regarded as priority, and values $\geq 0.60$ (Hair et al., 1998) as acceptable. Cronbach's alpha statistic is used for evaluation of indicators of which one might ask to what extent they „measure the 
same thing". All indicators, which confirm reliability of claims relative to the basic dimensions construct, were estimated (Anderson \& Gerbing, 1988; Iglesias \& Vázquez, 2001).

Measurements in our study confirm convergent validity which is an indication of the extent to which the indicators used for measuring a particular concept really relate to that concept. The share of explained variance indicators is higher than 0.5 (AVE $\geq$ $0.5)$ which points to the fact that there is more variation in the variables associated to given construct, which can be seen in data given in Table 1.

After estimated measuring model by using confirmatory factor analysis with the purpose of determining whether there is reliability among changing variables, shows that all factor loadings are important $(\mathrm{p}>0.5)$ (Fornell \& Larcker, 1981). Structural relations have been tested, afterwards, by using the multi- group confirmatory factor analysis, which indicates significant differences of factor loadings in certified and non-certified companies.

\subsection{Testing hypothesis}

In order to both analyze data and test the hypotheses, the sample was divided into two groups - a sample named "certified" (companies with certified management system) on one side and "non-certified" companies on the other one. The first analysis tested the existence of significant differences for the analysis of cooperation with suppliers between these two groups of

Table 1. The confirmatory factor analysis

\begin{tabular}{|c|c|c|c|c|c|c|}
\hline Construct $(\mathbf{F x})$ & & $\begin{array}{c}\text { Non- } \\
\text { standard } \\
\text { factor } \\
\text { loadings }\end{array}$ & T-values & $\begin{array}{l}\text { Standard } \\
\text { factor } \\
\text { loadings }\end{array}$ & $\begin{array}{c}\text { Convergent } \\
\text { validity }\end{array}$ & $\begin{array}{l}\text { Cronbach } \\
\text { alpha }(\alpha)\end{array}$ \\
\hline $\begin{array}{l}\text { Communication } \\
\text { (F1) }\end{array}$ & $\begin{array}{l}\text { INF4 } \\
\text { INF3 } \\
\text { INF2 } \\
\text { INF1 }\end{array}$ & $\begin{array}{l}1.000 \\
0.991 \\
0.920 \\
1.039\end{array}$ & $\begin{array}{l}12.534 \\
12.124 \\
13.010\end{array}$ & $\begin{array}{l}0.723 \\
0.739 \\
0.719 \\
0.755\end{array}$ & 0.538 & 0.823 \\
\hline Trust (F2) & $\begin{array}{l}\text { T4 } \\
\text { T3 } \\
\text { T2 } \\
\text { T1 }\end{array}$ & $\begin{array}{l}1.000 \\
1.103 \\
1.182 \\
0.893\end{array}$ & $\begin{array}{l}13.804 \\
14.668 \\
12.044\end{array}$ & $\begin{array}{l}0.728 \\
0.767 \\
0.832 \\
0.671\end{array}$ & 0.565 & 0.835 \\
\hline Commitment (F3) & $\begin{array}{l}\text { CM4 } \\
\text { CM3 } \\
\text { CM2 } \\
\text { CM1 }\end{array}$ & $\begin{array}{l}1.000 \\
1.015 \\
1.148 \\
1.219\end{array}$ & $\begin{array}{l}13.163 \\
12.941 \\
12.611\end{array}$ & $\begin{array}{l}0.687 \\
0.765 \\
0.775 \\
0.753\end{array}$ & 0.556 & 0.829 \\
\hline $\begin{array}{l}\text { Long term } \\
\text { orientation (F4) }\end{array}$ & $\begin{array}{l}\text { OR3 } \\
\text { OR2 } \\
\text { OR1 }\end{array}$ & $\begin{array}{l}1.000 \\
1.001 \\
0.982\end{array}$ & $\begin{array}{l}20.347 \\
17.828\end{array}$ & $\begin{array}{l}0.854 \\
0.871 \\
0.802\end{array}$ & 0.710 & 0.841 \\
\hline Satisfaction (F5) & $\begin{array}{l}\text { S4 } \\
\text { S3 } \\
\text { S2 } \\
\text { S1 }\end{array}$ & $\begin{array}{l}1.000 \\
1.230 \\
1.131 \\
1.158\end{array}$ & $\begin{array}{l}18.244 \\
16.673 \\
17.765\end{array}$ & $\begin{array}{l}0.807 \\
0.836 \\
0.791 \\
0.834\end{array}$ & 0.667 & 0.888 \\
\hline Cooperation (F6) & $\begin{array}{l}\mathrm{CP} 3 \\
\mathrm{CP} 2 \\
\mathrm{CP} 3\end{array}$ & $\begin{array}{l}1.000 \\
1.226 \\
1.105\end{array}$ & $\begin{array}{l}9.236 \\
7.773\end{array}$ & $\begin{array}{l}0.543 \\
0.689 \\
0.536\end{array}$ & 0.352 & 0.643 \\
\hline
\end{tabular}


companies (Iglesias \& Vázquez, 2001; Byrne, 2010). In order to test the differences in the factor loading, it is necessary to set up separate, but identical measuring models for certified as well as non-certified companies, Table 2.

This analysis includes coefficients of two samples so the results could be compared. Table 2 shows that constructs have similar structures in both samples and that factor loadings have statistical relevance $(\mathrm{p}>0.5)$. Model comparison indicates that there are no significant differences between the model (Milia et al., 2005) and critical ratio of differences among certified regression coefficients $(<1.96 ; \mathrm{p}>0.05)$. The following analysis presents chi-square goodness-of-fit statistic which views relations of variant and invariant models, Table 3.

The results show that model set like this leads to statistically significant reduction in size of chi-square $(p<0.001)$ in relation to two tested models, both variant and invariant. Increased fit indexes PNFI, AIC and RMSEA indicate that invariant model fitted obtained data in a better way $(\mathrm{Hu} \&$ Bentler, 1999) when compared to the variant model. Table 3 presents chi-square goodness-of-fit statistic, comparative fit index, and statistics of model comparison for both groups of models simultaneously (Byrne, 2010). Chi-square values for both

Table 2. Multi-group confirmatory factor analysis

\begin{tabular}{|c|c|c|c|c|c|c|c|c|c|}
\hline & & \multicolumn{4}{|c|}{ Standardized companies $(n=186)$} & \multicolumn{4}{|c|}{ Non-standardized companies $(n=170)$} \\
\hline Construct $(\mathbf{F x})$ & & $\begin{array}{l}\text { Standard } \\
\text { factor } \\
\text { loadings }\end{array}$ & C.R. & AVE & $\alpha$ & $\begin{array}{l}\text { Standard } \\
\text { factor } \\
\text { loadings }\end{array}$ & C.R. & AVE & $\alpha$ \\
\hline Communication (F1) & $\begin{array}{l}\text { INF4 } \\
\text { INF3 } \\
\text { INF2 } \\
\text { INF1 }\end{array}$ & $\begin{array}{l}0.737 \\
0.627 \\
0.614 \\
0.740\end{array}$ & $\begin{array}{l}7.904 \\
7.786 \\
12.926\end{array}$ & 0.465 & 0.786 & $\begin{array}{l}0.756 \\
0.792 \\
0.746 \\
0.778\end{array}$ & $\begin{array}{l}10.869 \\
10.019 \\
12.926\end{array}$ & 0.590 & 0.844 \\
\hline Trust (F2) & $\begin{array}{l}\mathrm{T} 4 \\
\mathrm{~T} 3 \\
\mathrm{~T} 2 \\
\mathrm{~T} 1\end{array}$ & $\begin{array}{l}0.692 \\
0.750 \\
0.737 \\
0.661\end{array}$ & $\begin{array}{l}13.585 \\
10.107 \\
11.863\end{array}$ & 0.505 & 0.828 & $\begin{array}{l}0.759 \\
0.768 \\
0.860 \\
0.682\end{array}$ & $\begin{array}{l}13.585 \\
13.411 \\
11.863\end{array}$ & 0.592 & 0.842 \\
\hline Commitment (F3) & $\begin{array}{l}\text { CM4 } \\
\text { CM3 } \\
\text { CM2 } \\
\text { CM1 }\end{array}$ & $\begin{array}{l}0.705 \\
0.791 \\
0.855 \\
0.757\end{array}$ & $\begin{array}{l}13.153 \\
12.904 \\
12.219\end{array}$ & 0.607 & 0.846 & $\begin{array}{l}0.671 \\
0.770 \\
0.741 \\
0.730\end{array}$ & $\begin{array}{l}13.153 \\
12.904 \\
12.219\end{array}$ & 0.531 & 0.815 \\
\hline Long term orient $(\mathrm{F} 4)$ & $\begin{array}{l}\text { OR3 } \\
\text { OR2 } \\
\text { OR1 }\end{array}$ & $\begin{array}{l}0.863 \\
0.885 \\
0.770\end{array}$ & $\begin{array}{l}19.744 \\
17.349\end{array}$ & 0.707 & 0.850 & $\begin{array}{l}0.832 \\
0.872 \\
0.825\end{array}$ & $\begin{array}{l}19.744 \\
17.349\end{array}$ & 0.711 & 0.895 \\
\hline Satisfaction (F5) & $\begin{array}{l}\text { S4 } \\
\text { S3 } \\
\text { S2 } \\
\text { S1 }\end{array}$ & $\begin{array}{l}0.769 \\
0.775 \\
0.739 \\
0.771\end{array}$ & $\begin{array}{l}16.661 \\
15.485 \\
16.587\end{array}$ & 0.583 & 0.840 & $\begin{array}{l}0.789 \\
0.830 \\
0.789 \\
0.842\end{array}$ & $\begin{array}{l}16.661 \\
15.485 \\
16.587\end{array}$ & 0.660 & 0.913 \\
\hline Cooperation (F6) & $\begin{array}{l}\text { CP3 } \\
\text { CP2 } \\
\text { CP3 }\end{array}$ & $\begin{array}{l}0.549 \\
0.721 \\
0.547\end{array}$ & $\begin{array}{l}8.936 \\
7.221\end{array}$ & 0.373 & 0.630 & $\begin{array}{l}0.541 \\
0.705 \\
0.490\end{array}$ & $\begin{array}{l}8.936 \\
7.221\end{array}$ & 0.343 & 0.578 \\
\hline
\end{tabular}


Table 3. Fit of index

\begin{tabular}{|c|c|c|c|c|c|c|c|c|c|c|}
\hline Model & $x^{2}$ & df & $x^{2} / \mathrm{df}$ & $\mathbf{p}$ & IFI & TLI & CFI & PNFI & AIC & RMSEA \\
\hline Independence & 5183 & 462 & 11.220 & $<0.0001$ & 0.00 & 0.00 & 0.00 & 0.00 & 5271.660 & 0.170 \\
\hline $\begin{array}{l}\text { 22-item- } \\
\text { invariant }(\mathrm{A})\end{array}$ & 961.341 & 423 & 2.272 & $<0.0001$ & 0.891 & 0.880 & 0.890 & 0.746 & 1127.341 & 0.059 \\
\hline $\begin{array}{l}\text { 22-item- } \\
\text { variant (B) }\end{array}$ & 922.224 & 415 & 2.223 & $<0.0001$ & 0.904 & 0.891 & 0.903 & 0.738 & 1104.224 & 0.056 \\
\hline $\begin{array}{l}\text { Model A vs } \\
\text { Model B }\end{array}$ & 39.117 & 8 & 0.049 & $>0.05$ & & & & & & \\
\hline
\end{tabular}

$\mathrm{x}^{2}$, Goodness-of-fit values, incremental fit index (IFI), Tucker-Lewis index (TLI), comparative fit index(CFI), parsimony normed fit index (PNFI), Akaike information criterion (AIC), root mean square error of approximation (RMSEA) and RMSEA range (low, high)

models have statistical relevance, indices for model comparison, IFI, TLI, CFI and PNFI are close or higher than 0.9, upon recommendations (Hoyle \& Panter, 1995).

In the next, final step, suggested hypotheses were tested. Regression coefficients (b coefficient) in variant group for certified (sw) and non-certified (pw) companies, obtained after calculations for multi-group analysis are given in Table 4. The differences that exist between samples confirm the suggested hypotheses. In Table 4, factor effects are higher or lower depending on certification of management system, which can be seen in suggested hypothesis (H7) cooperation - satisfaction. Hypotheses commitment - trust (H3), trust satisfaction (H4), satisfaction - commitment (H5) are also confirmed, but, it should be emphasized that in the second case there is positive, though, weaker influence if management systems are certified. As for communication - trust (H1), communication - satisfaction (H2), and long-term orientation - satisfaction (H6) their non-standardized regression coefficients are quite close to each other. Although we have insufficient evidence to confirm this group of hypotheses, they confirm the trajectory we have suggested as well as statistical relevance. Hypothesis (H8) cooperation long-term orientation is not confirmed since the statistical relevance is lower than 0.05 $(\mathrm{p}<0.05)$.

Regression coefficient for both groups of companies has been tested, since the results $\mathrm{R}^{2}=0.704$ correspond to the sub-sample of "certified" companies and $\mathrm{R}^{2}=0.853$ corresponds to the group of "non-certified" companies. The model can explain the cooperation of companies and their suppliers in both groups of companies based on the direct influence of satisfaction on cooperation as well as indirect influence of communication, trust and commitment.

\section{CONCLUSION}

The main goal of this research was to analyze effects of companies' certification on achieving cooperation with their suppliers. It is obvious that cooperation among companies, when it comes to 
Table 4. Multi-sample analysis

\begin{tabular}{|c|c|c|c|}
\hline “Standardized" firms & $\begin{array}{l}\text { Non- } \\
\text { standardized } \\
\text { parameters }\end{array}$ & $T$-value & $\begin{array}{l}\text { Causal } \\
\text { relations }\end{array}$ \\
\hline Communication - trust & $0.667(a)$ & 8.225 & R1: yes \\
\hline Trust - commitment & $0.531(\mathrm{a})$ & 7.351 & R1: yes \\
\hline Communication - satisfaction & $0.142(a)$ & 2.722 & R1: yes \\
\hline Trust - satisfaction & $0.279(\mathrm{a})$ & 4.065 & R1: yes \\
\hline Commitment - satisfaction & 0.399 (a) & 6.237 & R1: yes \\
\hline Satisfaction - long term orientation & $0.883(a)$ & 10.010 & R1: yes \\
\hline Long term orientation - cooperation & $-0.166(b)$ & -1.297 & \\
\hline Cooperation - satisfaction & 1.095 (a) & 5.949 & $\mathrm{R} 1$ : yes \\
\hline "Non-standardized" firms & $\begin{array}{l}\text { Non- } \\
\text { standardized } \\
\text { parameters }\end{array}$ & $T$-value & $\begin{array}{l}\text { Causal } \\
\text { relations }\end{array}$ \\
\hline Communication - trust & $0.644(a)$ & 8.411 & R1: yes \\
\hline Trust - commitment & 0.693 (a) & 9.159 & R1: yes \\
\hline Communication - satisfaction & 0.173 (a) & 3.135 & R1: yes \\
\hline Trust - satisfaction & $0.452(a)$ & 4.018 & R1: yes \\
\hline Commitment - satisfaction & 0.467 (a) & 3.539 & R1: yes \\
\hline Satisfaction - long term orientation & 0.917 (a) & 12.367 & R1: yes \\
\hline Long term orientation - cooperation & $0.386(\mathrm{~b})$ & 2.687 & R1: yes \\
\hline Cooperation - satisfaction & $0.391(\mathrm{~b})$ & 2.682 & R1: yes \\
\hline
\end{tabular}

(a) Significant at the $99 \%$ level; (b) Significant at the $95 \%$ level.

certification, has certain advantages in synergetic effects such as reducing costs or increasing profit. However, negative economic effects can appear. For example, extremely close cooperation can lead to a monopolistic structure with all its disadvantages for the company (DIN , 2000).

Our results indicate that there is significant moderating influence on relationships we have suggested between satisfaction and cooperation, while remaining limitations, communication and trust, trust and commitment, trust and satisfaction, commitment and satisfaction, satisfaction and long-term orientation, confirm suggested trajectory of the model.

In the proposed and confirmed hypothesis (H7) cooperation - satisfaction relationship strength varies depending whether the companies are "certified" and "noncertified". Following hypotheses: commitment - trust (H3), trust - satisfaction (H4), satisfaction - commitment (H5) have also been confirmed but it should be emphasized that in this other case there is positive, but weaker influence if management systems are certified. As for communication - trust (H1), communication - satisfaction (H2), and long-term orientation - satisfaction (H6), their non-certified regression coefficients are quite close to each other. Although we have insufficient evidence to confirm this group of hypotheses, they confirm the trajectory we have suggested as well as statistical relevance. The only relationship which has not been confirmed is (H8) long-term orientation - cooperation, since the statistical relevance is lower than $0.05(p<0.05)$. Responsibility that company must have introspectively in establishing long-term orientation in cooperation is both necessary and important. Companies must determine if they are capable of establishing relationship with their suppliers. In business literature it is clearly stated that the outcome of such 
point of view is positive, while inability to establish cooperation in long-term orientation may lead to a negative relationship which happens to be the case in our study.

The reason for this is the state of Serbian economy for the last few decades or even longer. Namely, in extremely volatile and changing business conditions in Serbia, which has been going through a transition period for a long time, there is a large number of small usually trading companies which are in a very unenviable position, so the real picture of all participants in the Serbian market is quite blurred.

Companies must, according to the law of probability, cooperate and procure raw materials and semi-finished products from suppliers that are not certified because they make $97.89 \%$ of companies in Serbia. This actually means - if cooperation between a certified and a non-certified company is beginning to take on a long-term orientation character, as a rule, the non-certified company develops over time and gradually organizes its management system and also as a rule it becomes aware of the importance of such organization. Since implementation of quality management system is a demanding venture, time consuming and financially challenging, companies avoid certifying it, due to the fact that there is probably a more suitable business partner for the survival of the company on the market. Hence hypothesis related to the need of forming a long-term orientation relationship has not been confirmed.

Certified companies make a lot of effort to meet the requirements of clearly defined standards. Therefore, they suggest "the best practice" for managing the relationship between customer and supplier in the supply chain. However, relevant studies (Ming et al., 2014) show that performances of a relationship in the context of the supply chain are not only a technical problem whose solution of "the best practice" would be blindly adopted, but it is a concept based on comprehension of closely attached concepts of cooperation: trust, satisfaction and commitment and issues related.

This paper presents analysis which has confirmed that the effects of co-operation between companies and suppliers at perception of satisfaction level (Ming et al., 2014) show significant differences in the function of certification within their business systems. Cooperation between certified companies and their suppliers is more successful and gives better results at a positive level of communication/information exchange, trust and commitment, stemming from their regulated management system, which involves decision making based on facts, a better knowledge of the needs and expectations of their customers as well as systemic approach to work (ISO 9000). Therefore, expectations which they have when it comes to their suppliers are clearly defined, thus their communication is unambiguous, precise, neat-always corroborated by appropriate records. The relationship that companies and suppliers build in such conditions is mutually beneficial and should also give the expected positive effects, as this paper has confirmed.

Future research will focus on studying suppliers, so that the blurred image on the market scene would become clear and give a real insight into company - supplier cooperation. The goal of this research would be to examine the relationship of all possible variants of a given relationship in terms of their certification or non-certification in order to draw explicit conclusions concerning this relationship. 


\title{
ЕФЕКТИ СЕРТИФИКАЦИЈЕ КВАЛИТЕТА КОД УСПОСТАВЉАҢА И РАЗВОЈА ОДНОСА КУПАЦ- ИСПОРУЧИЛАЦ
}

\author{
Исидора Милошевић, Ана Трајковић, Тамара Рајић, \\ Ђорђе Николић и Санела Арсић
}

\section{Извод}

Однос компанија - испоручилац је изузетно важан за успех компаније, што нам говори да је потребно максимизирати поверење и сарадњу на постављању и достизању циљева. У овом раду дат је преглед тог односа, компанија - испоручилац, са аспекта "сертификованих" и “несертификованих” компанија у Србији. Иако је број несертификованих компанија у Србији још увек далеко већи од сертификованих, компаније које су исказале већи интерес да узму учешћа у овом истраживању су управо оне које имају и тежњу за сопственим уређењем система менаџмента квалитетом, иако оне представљају само $2.11 \%$ укупног броја компанија у Србији. Подаци прикупљени у овој студији анализирани су у моделу структурних једначина (CEM), у којој су мултигрупном конфирматорском факторском анализом (МГЦФА) изведена упоредна мерења помоћу два узорка из различитих компанија, сертификованих и несертификованих.

Кључне речи: сарадња, сертификација, ефекат, систем управљања квалитетом.

\section{References}

Anderson, J.C., \& Gerbing, D. (1988). Structural modelling in practice: A review and recommended two-steps approach. Psychological Bulletin, 10, 411-423.

Arbuckle, J.L. (2009). Amos 18 user's guide. Crawfordville, FL: Amos Development Corporation.

Baptista, C. (2013). Interaction processes in long-term relationships in the metal mining industry: Longitudinal case studies of capital equipment buying. Industrial Marketing Management, 42, 969-982.

Baumgartner, H., \& Homburg, C. (1996). Applications of structural equation modelling in marketing and consumer research: A review. International Journal of Research in Marketing, 13, 139-161.
Byrne, B.M. (2004). Testing for multigroup invariance using graphics: A road less travelled. Structural Equation Modelling, 11 (2), 272-300.

Byrne, B.M. (2010). Structural equation modelling with AMOS. Basic concepts, applications, and programming (2nd ed.), Routledge, Taylor \& Francis Group, New York.

Cannon, J., \& Homburg, C. (2001). Customer-supplier relationships and customer firm costs. Journal of Marketing, 65, 29-43.

Capó-Vicedo, J., Mula, J., \& Capó, J. (2011). A social network-based organizational model for improving knowledge management in supply chains. Supply Chain Management: An International Journal, 16 (4), 284-293. 
Carr, A.S., \& Kaynak, H. (2007). Communication methods, information sharing, supplier development and performance: an empirical study of their relationships. International Journal of Operations and Production Management, 27 (4), 346-370.

Casadesús, M., \& Karapetrović, S. (2005). The erosion of ISO 9000 benefits: A temporal study. The International Journal of Quality \& Reliability Management, 22 (2), 120-136.

Castka, P., \& Balzarova, M.A. (2008). The impact of ISO 9000 and ISO 14000 on standardisation of social responsibility - an inside perspective. International Journal of Production Economics, 113, 74-87.

Chen, C., Chen, X.P., \& Meindl, J.R. (1998). How can cooperation be fostered? The cultural effects of individualism collectivism. Academy of Management Review, 23 (2), 285-304.

DIN. (2000). The Economic Benefits of Standardisation. DIN German Institute of Standardisation, Berlin.

Elg, U., Deligonul, S.Z., Ghauri, P.N., Danis, W., \& Tarnovskaya, V. (2012). Market-driving strategy implementation through global supplier relationships. Industrial Marketing Management, 41, 919928.

Fornell, C., \& Larcker, D.F. (1981). Evaluating Structural Equation Models with Unobservable Variables and Measurement Error. Journal of Marketing Research, 18 (1), 39-50.

Gülçin, B., \& Jbid, A. (2012). Collaborative product development: a literature Overview. Production Planning \& Control, 23 (1), 47-66.

Hair, J.F., Anderson, R.E., Tatham, R.L., \& Black, W.C. (1998). Multivariate Data Analysis with Reading, Prentice - Hall,
Englewood Cliffs, NJ.

Hair, J.F., Black, W.C., Babin, B.J., \& Anderson, R.E. (2010). Multivariate Data Analysis: A Global Perspective (7th ed.), Pearson Education, Upper Saddle River.

Holmen, E., Aune, T.B., \& Pedersen, A.C. (2013). Network pictures for managing key supplier relationships. Industrial Marketing Management, 42, 139-151.

Hoyle, R.H., \& Panter, A.T. (1995). Writing about structural equation models. In R.H. Hoyle (Ed.), Structural equation modeling: Concepts, issues, and applications 158-176. Thousand Oaks, CA: Sage Publications.

Hu, L., \& Bentler, P.M. (1999). Cut off criteria for fit indexes in covariance structure analysis: Conventional criteria versus new alternatives. Structural Equation Modelling. A Multidisciplinary Journal, 6 (1), 1-55.

Hung, K.-P., \& Lin, C.-K. (2013). More communication is not always better? The interplay between effective communication and interpersonal conflict in influencing satisfaction. Industrial Marketing Management, 42, 1223-1232.

Iglesias, V., \& Vázquez, R. (2001). The moderating effect of exclusive dealing agreements on distributor satisfaction. Journal of Strategic Marketing, 9, 215-231.

Ivens, B.S., van de Vijver, M., \& Vos, B. (2013). Managing and developing key supplier relationships: An introduction to the special issue, discussion and implications. Industrial Marketing Management, 42, 135138.

Kauffman, R.J., \& Tsai, J.Y. (2010). With or without you: The countervailing forces and effects of process standardization. Electronic Commerce Research and Applications, 9, 305-322.

Kwon, I.-W.G., \& Suh, T. (2005). Trust, commitment and relationships in supply 
chain management: a path analysis. Supply Chain Management: An International Journal, 10 (1), 26-33.

Leonidou, L.C., Talias, M.A., \& Leonidou, C.N. (2008). Exercised power as a driver of trust and commitment in crossborder industrial customer-seller relationships. Industrial Marketing Management, 37, 92-103.

Maloni, M., \& Benton, W.C. (2000). Power influences in the supply chain. Journal of Business Logistics, 21 (1), 49-73.

McDowell, W.C., Harris, M.L., \& Gibson, S.G. (2013). The Influence of Communication and Information Quality on Trust in the Small Business Supply Chain. The Journal of Applied Management and Entrepreneurship, 18, 21-38.

Metcalf, L.E., Frear, C.R., \& Krishnan, R. (1992). Buyer-seller relationships: An application of the IMP interaction model. European Journal of Marketing, 26 (2), 2746.

Milia, L.D., Smith, P.A., \& Folkard, S. (2005). A validation of the revised circadian type inventory in a working sample. Personality and Individual Differences, 39, 1293-1305.

Ming, Y., Grabot, B., \& Houé, R. (2014). A typology of the situations of cooperation in supply chains. Computers \& Industrial Engineering, 67, 56-71.

Mitra, S., \& Datta, P. (2014). Adoption of green supply chain management practices and their impact on performance: an exploratory study of Indian manufacturing firms. International Journal of Production Research, 52 (7), 2085-2107.

Modi, S.B., \& Mabert, V.A. (2007). Supplier development: Improving supplier performance e through knowledge transfer. Journal of Operations Management, 25 (1), 42-64.
Mohr, J., Fischer, R., \& Nevin, J. (1996). Collaborative communication in interfirm relationships: Moderating effects of integration and control. Journal of Marketing, 60, 103-115.

Nannally, J.C. (1978). Psychometric Theory, Second ed. McGraw-Hill, New York Obal, M., \& Lancioni, R.A. (2013). Maximizing customer-supplier relationships in the Digital Era: Concept and research agenda. Industrial Marketing Management, 42, 851-854.

Palmatier, R., Dant, R., Grewal, D., \& Evans, K. (2006). Factors influencing the effectiveness of relationship marketing: A meta-analysis. Journal of Marketing, 70 (4), 136-153.

Parkhe, A. (1993). Strategic alliance structuring: A game theoretic and transaction cost examination of interfirm cooperation. Academy of Management Journal, 36 (4), 794-829.

Paulo, A.C.A., Pedro, M.T.L., \& Ribeiro, A.C. (2014). ISO 9001 European Scoreboard: an instrument to measure macro quality. Total Quality Management \& Business Excellence, 25, (3/4), 309-318.

Ploetner, O., \& Ehret, M. (2006). From relationships to partnerships - new forms of cooperation between customer and seller. Industrial Marketing Management, 35, 4-9.

Redondo, Y.P., \& Fierro, J.C. (2008). Influence of the standardization of a firm's productive process on the long-term orientation of its supply relationships: An empirical study. Industrial Marketing Management, 37, 407-420.

Selnes, F. (1998). Antecedents and consequences of trust and satisfaction in customer-seller relationships. European Journal of Marketing, 32, 305-322.

Sharma, S. (2013). Development of supplier relationship including cost of 
defectives in the cyclic production. Production Planning \& Control, 24 (8-9), 759-768.

Squire, B., Cousins, P.D., Lawson, B., \& Brown, S. (2009). The effect of supplier manufacturing capabilities on buyer responsiveness: the role of collaboration. International Journal of Operations and Production Management, 29 (8), 766-788.

Stanko, M.A., Bonner, J.M., \& Calantone, R.J. (2007). Building commitment in customer-seller relationships: A tie strength perspective. Industrial Marketing Management, 36 (8), 1094-1103.

Stern, L.W., \& Reve, T. (1980). Distribution channels as political economies: A framework for competitive analysis. Journal of Marketing, 44, 52-64.

Stevenson, T., \& Barnes, F. (2002). What industrial marketers need to know about ISO 9000 certification; a review, update and integration with marketing. Industrial Marketing Management, 31, 695-703.

Voldnes, G., Grønhaug, K., \& Nilssen, F. (2012). Satisfaction in customer-seller relationships - Influence of cultural differences. Industrial Marketing Management, 41, 1081-1093.

Walter, A., Müller, T., Helfert, G., \& Ritter, H. (2003). Functions of industrial supplier relationships and their impact on relationship quality. Industrial Marketing Management, 32, 159-169.

Webster, F.E. (1992). The changing role of marketing in the corporation. Journal of Marketing, 50, 1-17.

Wu, Z., Steward, M.D., \& Hartley, J.L. (2010). Wearing many hats: Supply managers' behavioural complexity and its impact on supplier relationships. Journal of Business Research, 63 (8), 817-823.

Yen, Y., Wang, E.S., \& Horng, D. (2011). Suppliers' willingness of customization, effective communication, and trust: A study of switching cost antecedents. The Journal of Business and Industrial Marketing, 26 (4), 250-259.

Živković, D., Živković, Ž., Manasijević, D., \& Kostadinović, M. (2010). Investigation of the knowledge combination interrelations between SMEs and consumer/supplier network. Serbian Journal of Management, 5 (2), 261-273. 